3-1-2011

\title{
Transparent U.S. Monetary Policy: Theory and Tests
}

Marc D. Hayford

Loyola University Chicago

Anastasios G. Malliaris

Loyola University Chicago, tmallia@luc.edu

Follow this and additional works at: https://ecommons.luc.edu/business_facpubs

Part of the Business Commons

\section{Author Manuscript}

This is a pre-publication author manuscript of the final, published article.

\section{Recommended Citation}

Hayford, Marc D. and Malliaris, Anastasios G.. Transparent U.S. Monetary Policy: Theory and Tests. Applied Economics, 44, 7: 813-824, 2011. Retrieved from Loyola eCommons, School of Business: Faculty Publications and Other Works, http://dx.doi.org/10.1080/00036846.2010.524628

This Article is brought to you for free and open access by the Faculty Publications and Other Works by Department at Loyola eCommons. It has been accepted for inclusion in School of Business: Faculty Publications and Other Works by an authorized administrator of Loyola eCommons. For more information, please contact ecommons@luc.edu.

\section{(c) $($ () $\ominus$}

This work is licensed under a Creative Commons Attribution-Noncommercial-No Derivative Works 3.0 License.

(C) Taylor \& Francis 2012 


\title{
Transparent Monetary Policy
}

\author{
Marc D. Hayford and \\ A.G. Malliaris \\ Department of Economics \\ Loyola University Chicago \\ 1 East Pearson Street \\ Chicago, Illinois 60611 \\ tmallia@luc.edu \\ mhayfor@luc.edu
}

\begin{abstract}
In 1994 the Federal Reserve System moved to a more transparent reporting of monetary policy. In this paper we first discuss the evolution of Federal Reserve transparency in U.S. and second we test its effectiveness. We assess the empirical impact of monetary policy transparency on the uncertainty about future monetary policy using T-bill rate forecast dispersions from the Survey of Professional Forecasters as a proxy for monetary policy uncertainty. We use three statistical methodologies: descriptive statistics, single regression equations and a vector autoregressive model. The empirical findings confirm that Federal Reserve transparency has reduced the uncertainty of future monetary policy anticipated by market participants.
\end{abstract}

JEL Classification: E44, E52, E58

Current version: July 10, 2007. An earlier draft was presented at the Annual Western Economic Association International Meetings in Seattle, June 29-July 3, 2007. The authors are thankful to George Kaufman, James Brox, Harvey Rosenblum for useful comments and to Robert DeYoung who discussed the paper and offered numerous helpful suggestions. We are also thankful to co-editor Steve Yamarik who has helped us refocus the paper. All remaining errors are the authors' responsibility. 


\section{Transparent Monetary Policy}

\section{Introduction}

Chairman Greenspan (2004) in his address to the American Economic Association argued that the Federal Reserve’s experiences over the past two decades” make it clear that uncertainty is not just a pervasive feature of the monetary policy landscape; it is the defining characteristic of the landscape” (Greenspan (2004, p.36)). Further elaborating the notion of monetary policy under uncertainty, at the Fourth Conference on the International Research Forum on Monetary Policy, Vice Chairman of the Federal Reserve Board of Governors Donald L. Kohn (2006) discussed in detail the role of uncertainty and its influence on the formulation of monetary policy.

In this paper we discuss (1) how the Federal Reserve Bank under the Chairmanship of Alan Greenspan took several initiatives to reduce uncertainty about future monetary policy by becoming more transparent. We, then (2) assess the empirical impact of monetary policy transparency on the uncertainty about future monetary policy using Tbill rate forecast dispersions from the Survey of Professional Forecasters as a proxy for monetary policy uncertainty.

\section{Central Bank Transparency}


In view of the fact that the Fed has been given enormous economic responsibilities to preserve price stability and promote economic growth, the question naturally arises as to how the Fed should exercise its responsibilities in a democratic society guided by institutions of freedom and accountability. Academic economists and policy makers agree that the Fed's accountability for its actions to preserve low inflation and promote economic growth is best expressed in its degree of transparency.

The standard definition of transparency is the commitment of the Central Bank to provide reliable, complete, and timely information to the widest possible audience. A more theoretical definition of transparency that is widely used in the literature is the lack of asymmetric information between monetary policy makers and economic agents. This is equivalent to saying that transparency describes the presence of symmetry of information between policy makers and economic agents.

Transparency has multiple attributes each of which is essential to maintaining the meaning of the concept. Thus failure to provide information, providing unreliable information, providing it in an untimely way, or providing information that is abstruse or difficult to understand violates the integrity of the concept. These issues are discussed in detail in Ferguson (2001), Carpenter (2004), Issing (2005) Haan et al (2007).

Historically speaking, transparency as it relates to monetary policies of the Federal Reserve and Central Banks around the world was not a top priority. In fact for a long time, the actions, policies and objectives of central banks were shrouded in secrecy. The change in approach is due in part to the recognition by central bankers of the economic benefits of more transparency about the design, procedures, and tools employed in carrying out the policies. 
In the U.S, there has been an evolution in the practice of transparency at the Federal Reserve. This evolution can be separated into two multiple dimensions. With regard to transparency concerning policy objectives, the road began with the Freedom of Information Act, which took effect in 1967. As a result of this act, FOMC began to publish the proceeding of the minutes of the Fed meetings. However, the minutes were divided into two documents. One was called the Memorandum of Discussion, which was released after a five-year lag. This document identified the speakers and contributors, but was not a verbatim transcript. The other was a shorter document called the Record of Policy Action, which was released with relatively little delay. This document provided a summary of the committee’s deliberation and discussion but did not identify which FOMC member took which position.

In 1979, in response to a court suit challenging the legality of delay of the release of the Memorandum, the FOMC discontinued its publication. The FOMC continues to publish the Record of Policy Action but in 1993 changed its name to "Minutes of FOMC Meetings.” Over time, the release lag of this document was shortened and currently is available two days after the next scheduled FOMC meeting.

Transparency of FOMC with respect to policy actions has improved considerably over the past 10 years. Beginning in 1994, under the leadership of Chairman Alan Greenspan, the Federal Reserve System went through a series of changes in the reporting of monetary policy. Prior to February 1994, financial market participants had to guess, infer or estimate the current target of the Federal funds rate as well as the likely future path of monetary policy. A number of economists, some of whom had previously worked for the 
Federal Reserve System worked as "Fed Watchers” with the task of divining monetary policy.

Starting in February 1994, the post FOMC meeting press releases began to signal changes in the Federal funds rate target without explicitly stating the target. When no post meeting statement was released this was taken to signal no change in the Fed funds target.

Beginning with the July 1995 FOMC meeting the Fed began to explicitly state the Fed funds target. Starting with the May 1999 FOMC meeting, in addition to the Fed funds target announcement, the post meeting statements began to include the reasoning behind the target level as well as an indication of the expected future path of the Federal funds rate. A detailed historical analysis of the evolution of central bank transparency in the U.S. is found in Poole (2005a), Carlson et al (2006) and Moskow (2006).

\section{Empirical Assessment of Impact of Monetary Policy Transparency}

Having briefly discussed the concept of transparency and its recent evolution in the U.S. we next investigate empirically its impact. There is only a small set of empirical papers since the implementation of Fed transparency is only about 12 years old. Carpenter (2004) reviews few of these empirical studies.

In our empirical investigation, as a proxy for the various sources of uncertainty about future monetary policy we use the forecast dispersions for T-bills from the Survey of Professional Forecasters (SPF). We use these data for three reasons.

First, since the T-bill rate closely tracks the Federal funds rate, it seems plausible that forecasters of the T-bill rate are essentially attempting to forecast future monetary policy. Figure 1 shows the close relationship (correlation $=0.996$ ) between the Federal funds rate 
and the three-month T-bill rate since 1981. Clearly movements in the T-bill rate closely track the Federal funds rate. Hence we assume that forecasters of the future T-bill rate are influenced in large degree by what they think the Fed is going to do with future monetary policy.

The second reason is that survey based forecasts predict well. Ang, Bekaert and Wei (2006) provide detailed evidence about the relative performance of four alternative methods of forecasting out-of-sample inflation in the U.S.: time series ARIMA models, regressions using Phillips curve modeling, term structure models that include linear, nonlinear and arbitrage-free modeling and survey-based measures. They find that survey forecasts outperform the other econometric methods.

The third reason we use T-bill data is that the Survey of Professional Forecasters provides data on forecasts on the future three month T-bill rate. Calculating the forecast dispersion, (i.e. the standard deviation of these forecasts across forecasters) provides us with a proxy for uncertainty about future monetary policy. The SPF is conducted by the Federal Reserve Bank of Philadelphia. The data is available on their web site (see http://www.phil.frb.org/econ/spf/index.html).

Since the third quarter of 1981, after the release of the advance NIPA data for previous quarter, that is in the beginning of February, May, August, and November, the SPF has asked a group of about 30 to 50 people who make a living as forecasters on Wall Street or in business for their forecast of the three month T-bill rate one to five quarters into the future. Using these forecasts from each, we proxy for uncertainty about future monetary policy as the standard deviation of these T-bill rate forecasts one to five quarters ahead $\left(S T F_{j t}\right)$ by calculating: 
(1) $S T F_{j t}=\sqrt{\sum_{i=1}^{n_{t}} \frac{\left(T F_{j t}^{i}-E\left(T F_{j t}\right)\right)^{2}}{n_{t}}}$

where $T F_{j t}^{i}$ is the three month T-bill forecast of forecaster $\mathrm{i}$, in quarter $\mathrm{t}$ and $E\left(T F_{j t}\right)$ is the mean forecast for quarter $\mathrm{t}$ and for both $\mathrm{j}=1,2,3,4,5$ quarters ahead. The number of forecasters each quarter is $n_{t}$ which varies from around 30 to 50 people. The hypothesis we wish to test is: Fed transparency reduces the standard deviation of T-bill rate forecasts. We employ three methodologies: descriptive statistics, single equation regression and vector autoregressions.

\section{Descriptive statistics}

Figure 2 shows the standard deviation of T-bill rate forecasts, our measure of forecast dispersion, one to five quarters ahead from the Survey of Professional Forecasters. For the aid of comparison the scale of the vertical axis of each graph is identical. Two things can be noted from figure 2. First, note that the standard deviation of forecasts was relatively higher in the early 1980s. Second, notice that the standard deviation of forecasts increases as the forecast horizon increases from two to five quarters ahead.

As can be seen in figure 2 a lot of the volatility in the forecast dispersion occurs in the early 1980s, although this is less true for the four to five quarters ahead forecasts than the nearer term forecasts. Some of the volatility in the forecast dispersion perhaps can be attributed to the transition to lower inflation following the recessions of the 1980 and 1981-82. By the end of 1983 inflation had stabilized around 4\% and we take this to be the end of the "first" transition to lower inflation.

Table 1 reports the mean of the forecast dispersions for the sample split according to the evolution of the transparency of monetary policy. The differences in the mean 
dispersions (tests not reported) are all statistically significantly different from the 1981:3 to $1993: 4$ pre-transparency sample as well as from the 1984:1 to 1993:4 sample. Also the changes in the mean dispersions are quite large. As shown in the table below the decline in the mean dispersion is between 25 and 50 percent. The second row of numbers uses the sample 1984:1 to 1993:4 as the "pre-transparency" period.

As discussed above during the sample period the intention of monetary policy makers was to increasingly make monetary policy more transparent. If the Fed has gotten better at communicating its intentions, then there should be a greater consensus on the path of future monetary policy and hence lower forecast dispersions on average. Hence to the extent that the Fed was successful at increasing transparency, the goal of which presumably is to reduce the uncertainty about monetary policy, the forecast dispersions should decrease. This indeed seems to be the case. Figure 2 and Table 1 both indicate that going from the 1980s into the 1990s and 2000s forecast dispersion has decreased.

Table 3 isolates spikes in the forecast dispersions. Spikes in the forecast dispersions are identified as values of STF1, STF2, STF3, STF4, or STF5 greater than or equal to their means plus one standard deviation. Table 3 reports the dates and magnitudes of the spikes. For the 91 quarters from 1984:1 to 2006:3 there are 34 quarters where at least one forecast dispersion spikes. In only two quarter do all five spike while in 13 quarters only one forecast dispersion spikes. With the exception of STF4, all forecast dispersions spike the between 13 and 17 times. Some of these spikes can be associated with changes in the stance of monetary policy and some with financial or political events.

Hence while the data plot and sample statistics alone suggests that the Fed has been successful at reducing uncertainty about future monetary policy the empirical question is 
what else might account for the decline in forecast dispersion other than the increase in the transparency of monetary policy. Table 3 suggests it is necessary to control for that the absolute size of the changes in the Federal funds and the occurrence of financial crises when estimating the impact of transparency on the forecast dispersion of T-bill.

\section{Single Equation Regression Models}

To estimate the impact of increased transparency on the market participant uncertainty about future monetary policy the following regression is estimated:

$$
\begin{aligned}
\operatorname{STF}_{j t}=\beta_{0}+\beta_{1} \mid & \Delta F F R_{t}\left|+\beta_{2} D_{k}+\beta_{3} D_{k} \times\right| \Delta F F R_{t} \mid \\
& +\beta_{4} 87 \mathrm{CRASH}_{t}+\beta_{5} \operatorname{ASIAN}_{t}+\beta_{6} \operatorname{RUSSIAN}_{t}+\beta_{7}{\operatorname{NINE} 11_{t}+\varepsilon_{t}}
\end{aligned}
$$

Right hand side variables are defined as follows: $\left|\Delta F F R_{t}\right|$ is the absolute value of the change in the Federal funds rate from the previous quarter. $D_{k}$ for $\mathrm{k}=94,95,99$ is a dummy variable that equals 1 beginning in 1994:1, 1995:4 and 1999:3 respectively and zero otherwise. Hence $D_{k}$ tracks the changes in the transparency of monetary policy. $87 \mathrm{CRASH}_{t}$ is a dummy for the 1987 stock market crash and equals 1 for 1987:4 and zero otherwise. $\operatorname{ASIAN}_{t}$ is the dummy for the Asian financial crisis and equals 1 for 1997:3 and zero otherwise. RUSSIAN ${ }_{t}$ is the dummy for the Russian/LTCM financial crisis and equals 1 for 1998:4 and zero otherwise. NINE11 is the dummy for 9/11 and equals 1 for 2001:4 and zero otherwise

Estimates of equation (2) are reported in table 4 for the 1 to 5 quarter ahead forecast dispersions of the 3 month T-bill rate. In discussing the results we first focus on the control variables and then the transparency variables. 
Tables 4a to 4e report that the coefficient on the absolute value of the change in the Federal funds rate is statistically significant for all regressions for $S T F_{j t}$, for $\mathrm{j}=1$ to 4 and the 2 out of the 6 specifications for $S T F_{5 t}$. The coefficients indicate that a 100 basis point change in the Federal funds rate increase the one quarter ahead forecast dispersion $S T F_{1 t}$ by 9 to 14 basis points or equivalently $50 \%$ to $70 \%$ of the sample mean for $S T F_{1 t}$. A similar magnitude result is obtained for the 2 quarter ahead forecast dispersion $S T F_{2 t}$. For the 3, 4 and 5 quarter ahead forecast dispersions, a 100 basis point change in the Federal funds rate results in an in forecast dispersions equivalent $30 \%$ to $50 \%$ of their sample means. These results indicate rather robustly that changes in the Federal funds rate generate statistically significant and large (relative to the sample mean) increases in forecast dispersion and hence uncertainty about future monetary policy. In addition the results indicate that the changes in the Federal funds rate generate more uncertainty 1 to 2 quarters ahead than 3 to 5 quarters ahead. One way to think about the goal of making monetary policy more transparent is that the Fed wants to reduce the impact of that changes in the Federal funds rate have on uncertainty about future monetary policy.

Tables 4a to 4e also report the coefficients on the various financial/political crisis variables. The coefficients for the 1987 stock market crash suggest that the crash increased forecast dispersions of the $\mathrm{T}$ bill rate for 1 quarter ahead by $73 \%$ to $100 \%$ of its sample mean, while the 2 quarter ahead $\mathrm{T}$ bill rate forecast dispersion increase $63 \%$ to $83 \%$ of its sample mean. All the 87CRASH coefficients are statistically significant in the $S T F_{2 t}$ regressions while 2 out of 3 are in the $S T F_{1 t}$ regression. For the 3, 4 and 5 quarter ahead forecast dispersions the 87CRASH coefficients indicate a 35\% to 72\% increase in forecast dispersion. However these coefficients are not statistically significant. Hence the 
1987 stock market crash did increase forecast dispersion for the T-bill rate. Further the increase in forecast dispersion was large, between $35 \%$ and $100 \%$ of the forecast dispersion sample mean depending on the regression, however the coefficients are only statistically significant for $S T F_{1 t}$ (2 out of 3 regressions) and $S T F_{2 t}$.

The Asian financial crisis resulted in a very large and statistically significant increase in the 1 quarter forecast dispersion $S T F_{1 t}: 373 \%$ to $400 \%$ of the sample mean.

For the 2 quarter ahead forecast dispersion the results are mixed: in two specifications the impact is small and statistically insignificant while in one specification (which controls only for the 1999 changes in monetary policy transparency) the impact of the crisis is large (237\% of the sample mean) and statistically significant. For the rest of the forecast dispersions the impact of the Asian crisis is small and statistically insignificant. Both the Russian financial crisis and 9/11 have a statistically insignificant impact on the $\mathrm{T}$ bill forecast dispersions at all horizons. That the 1987 crash had the biggest impact on forecast dispersion followed by the 1997 Asian financial crisis and given that the 1998 Russian/LTCM crisis and 9/11/2001 have essentially no impact on forecast dispersion is consistent with monetary policy transparency reducing the impact on external shocks on the short debt market.

Now we will discuss our estimated impact of transparency on the $\mathrm{T}$ bill forecast dispersions. Table 4a to 4e report the coefficients on the transparency dummies, $D_{k}$ for $\mathrm{k}$ $=94,95,99$ as well as the interaction of the dummies with the absolute value of the change in the Federal funds rate, $D_{k} \times\left|\Delta F F R_{t}\right|$ for $\mathrm{k}=94,95,99$.

For the 1 quarter ahead forecast dispersion, $S T F_{1 t}$ the coefficients on $D_{k}$ for $\mathrm{k}=94$, 95, 99 not controlling for financial crises (Table 4a, column 2, 4, and 6) suggest a 
reduction in forecast dispersion of $-7,-6$ and -7 basis points respectively with only first estimate being statistically significant. Controlling for financial crises (Table 4a, column 3,5 , and 7), the coefficients on $D_{k}$ for $\mathrm{k}=94,95,99$ suggest a reduction in forecast dispersion of -10 , -8 and -4 basis points with the first two estimates being statistically significant. This suggests the introduction of transparency resulted in a reduction the average forecast dispersion by about $-20 \%$ to $-50 \%$ of the sample mean. The coefficients on the interaction term $D_{k} \times\left|\Delta F F R_{t}\right|$ for $\mathrm{k}=94,95,99$ are all positive but statistically insignificant. Hence for the 1 quarter ahead forecast dispersions there evidence that the changes in the transparency of monetary policy resulted in a large reduction in the average level of forecast dispersion, with essentially no change in the response of forecast dispersion to change in the Federal funds rate.

Tables $4 \mathrm{~b}$ and 4c give the results for the 2 and 3 quarter ahead forecast dispersions. The results are similar to the 1 quarter forecast dispersions: the coefficients on $D_{k}$ for $\mathrm{k}=$ 94, 95, 99 not controlling for financial crises (Table 4b and 4c, column 2, 4, and 6) suggest a reduction in forecast dispersion of $-9,-6$ and +1 basis points respectively for $S T F_{2 t}$ and $-9,-10$ and +1 reduction in forecast dispersion for $S T F_{3 t}$. The first two estimates for both $S T F_{2 t}$ and $S T F_{3 t}$ are also statistically significant. In terms of the sample means the reduction in the forecast dispersion is approximately $-20 \%$ to $-30 \%$ for the 2 quarter ahead forecast dispersion $S T F_{2 t}$ and approximately -21\% to-23\% for the three quarter ahead forecast dispersion $S T F_{3 t}$. Similar results are obtained with the regressions that include the controls for financial/political crises. The coefficients on the interaction term $D_{k} \times\left|\Delta F F R_{t}\right|$ for $\mathrm{k}=94,95,99$ in both the $S T F_{2 t}$ and $S T F_{3 t}$ regressions 
are negative which is consistent with increased transparency reducing uncertainty but statistically insignificant.

The results for the 4 and 5 quarter ahead forecast dispersions, given in Tables $4 \mathrm{~d}$ and 4e indicate a reduction in forecast dispersions by $-4 \%$ to $-32 \%$. However none of the estimates are statistically significantly different from zero. The same is true for

coefficients on the interaction term $D_{k} \times\left|\Delta F F R_{t}\right|$ for $\mathrm{k}=94,95,99$.

In summary, the biggest impact of the change in monetary policy transparency occurred in 1994 and 1995: the forecast dispersions decreased by $-20 \%$ to $-30 \%$ of the sample mean for the 1, 2 and 3 quarter ahead $\mathrm{T}$ bill forecasts. The range of the decrease in forecast dispersions is similar for the 4 and 5 quarter ahead forecast dispersions, although the estimates are not statistically significant. Thus our estimates suggest that controlling for financial/political crisis and the absolute value of the change in the Federal funds rate, the changes in monetary policy transparency introduced in 1994 and 19995 resulted in a large reduction in uncertainty about future monetary policy 1 to 3 quarters into the future. In other words the hypothesis claiming that central bank transparency has reduced future uncertainty about monetary policy cannot be rejected.

\section{Vector Autoregressions}

This section uses structural vector autoregressions (SVAR) to characterize the dynamic impact of economic and monetary policy on the T-bill rate forecast dispersion. SVARs have been used extensively in the empirical monetary policy literature (see for example Bernanke and Mihov (1998)).

The SVARs are estimated using quarterly data from 1981:3 to 2006:3. The general specification of the structural form of the models is given by: 
(3) $A X_{t}=B(L) X_{t-1}+\varepsilon_{t}$

where, $X_{t}$ is an $\mathrm{n} \mathrm{x} 1$ vector of endogenous variables, $\mathrm{A}$ is $\mathrm{n} \mathrm{x} \mathrm{n}$ parameter matrix with ones on the main diagonal and the off diagonal elements capturing the contemporaneous relationships between the variables, $\mathrm{B}(\mathrm{L})$ is a polynomial matrix in the lag operator, and $\varepsilon_{t}$ is an $\mathrm{n} \mathrm{x} 1$ vector of structural shocks. The standard or reduced forms VAR is given by (4) $X_{t}=D(L) X_{t-1}+\mu_{t}$

where $D(L)=A^{-1} B(L)$ and $\mu_{t}=A^{-1} \varepsilon_{t}$. Given estimates of the forecast errors of the standard form VAR $\mu_{t}$, a necessary condition for identification of the structural shocks, $\varepsilon_{t}$ can be obtained by imposing n(n-1)/2 restrictions on the A matrix (see Enders (1995) or Hamilton (1994)). The endogenous variable vector is given by $X_{t}^{\prime}=\left[I N F_{t}, U_{t}, F F R_{t}, S T F_{j t}\right]$. The variable $I N F_{t}$ is the growth rate from the same quarter of the pervious year of the consumption expenditure price excluding energy and food, $U_{t}$ is the unemployment rate and $F F R_{t}$ is the effective Federal funds rate. The data for these three variables comes from the Federal Reserve Bank of St. Louis: http://research.stlouisfed.org/fred2/. The structural shocks are given as $\varepsilon_{t}^{\prime}=\left[\varepsilon_{t}^{\mathrm{inf}}, \varepsilon_{t}^{u}, \varepsilon_{t}^{\mathrm{ffr}}, \varepsilon_{t}^{\mathrm{tfj}}\right]$. For the purposes of discussing identification and without loss of generality, rewrite equation (3) as:

$$
\left[\begin{array}{cccc}
1 & a_{12} & a_{13} & a_{14} \\
a_{21} & 1 & a_{23} & a_{24} \\
a_{31} & a_{32} & 1 & a_{34} \\
a_{41} & a_{42} & a_{43} & 1
\end{array}\right]\left[\begin{array}{c}
I N F_{t} \\
U_{t} \\
F F R_{t} \\
S T F_{j t}
\end{array}\right]=\left[\begin{array}{c}
\varepsilon_{t}^{\mathrm{inf}} \\
\varepsilon_{t}^{u} \\
\varepsilon_{t}^{f f r} \\
\varepsilon_{t}^{t f j}
\end{array}\right]
$$


The necessary condition to just identify the structural shocks is to impose restrictions on six of the elements of A. The traditional VAR approach to identification is assume the Choleski decomposition i.e. the assumption that the A matrix consists of zeros above the main diagonal. We will try to justify these restrictions structurally with the following assumptions:

1) Inflation is predetermined, and thus does not depend on contemporaneous values of the unemployment, the Federal funds rate or the T-bill rate forecast dispersion. The justification for this assumption is usual sticky wage and price model. With inflation predetermined, $a_{12}=a_{13}=a_{14}=0$

2) The unemployment rate is assumed to respond contemporaneously to inflation shocks, but not to financial market shocks via the Federal funds rate or the T-bill rate forecast dispersion. Hence $a_{23}=a_{24}=0$.

3) Finally, and with perhaps the least amount of justification, we assume that Fed in setting the Federal funds rate, is concerned solely with inflation and unemployment shocks, so $a_{34}=0$. This assumption is tenuous if the Fed responses to increases financial market uncertainty, i.e. an increase in forecast dispersion by changing (perhaps decreasing) the Federal funds rate.

\section{Discussion of the impulse response functions}

The impulse response functions for VAR discussed above are shown in Figures 3 a to e. The graphs in the third row in each figure can be interpreted as the estimated monetary policy rule for the full sample period. Regardless of the forecast dispersion measure, positive inflation shocks induce an increase in the Federal funds rate (although not 
always statistically significant) while positive unemployment shocks result in a comparably large and statistically significant decrease in the Federal funds rate. Interestingly, Federal funds rate increases in response to a positive shock to T-bill rate forecast dispersion one, two and three quarters ahead, while for 4 and 5 quarters ahead the Federal funds rate response is essentially zero. This seems a bit counterintuitive: As shown in Table 3, a positive shock to T-bill rate forecast dispersion seems likely to occur during a period of financial crisis (such as in the fall of 1998) which induces greater uncertainty about future interest rates. These results suggest that controlling for inflation and unemployment, such an increase in uncertainty is associated with restrictive monetary policy.

The graphs in the fourth row of figure 3 a to e, show for the response of the 1 to 5 quarter ahead $\mathrm{T}$ bill rate forecast dispersion for shocks to inflation, unemployment and the Federal funds rate. The initial impact of positive inflation shocks is to increase forecast dispersion from 1 to 4 ahead (statistically significant for 2 to 4 quarters ahead). Positive unemployment shocks increase $\mathrm{T}$ bill rate forecast dispersion after the initial impact quarter by more than inflation shocks. Shocks to the Federal funds rate, initially decreases forecast dispersion for the 1 to 3 quarters ahead forecast dispersion, with the impact being insignificantly different from zero after the first quarter. Shocks to the Federal funds rate have little impact on the 4 and 5 quarters $\mathrm{T}$ bill forecast dispersion. Overall the VAR results suggest that shocks to inflation, the unemployment rate and the Federal funds rate have a temporary impact on forecast dispersions and hence uncertainty about future monetary policy. This is consistent with the Fed's monetary policy 
transparency being successful in credibly communicating the future stance of monetary policy as well as the ultimate goals of monetary policy.

\section{Concluding remarks}

In this paper we first discuss the various sources of uncertainty that play an essential role in the formulation and conduct of monetary policy and evaluate the degree of uncertainty faced by monetary policy makers. Sources of uncertainty often include the following: uncertain economic data, uncertain economic forecasts, uncertainty in model building, uncertainty in the transmission of monetary policy and uncertainty due to globalization. Information about these various sources of uncertainty is not distributed symmetrically between the central bank and economic agents. Our discussion emphasized the desirability to eliminate such asymmetry of information between the central bank and economic agents by practicing a transparent monetary policy.

In the U.S., Fed transparency with respect to policy actions has improved considerably over the past 10 years. Beginning in 1994, under the leadership of Chairman Alan Greenspan, the Federal Reserve System went through a series of changes in the reporting of monetary policy. Prior to February 1994, financial market participants had to guess, infer or estimate the current target of the Federal funds rate as well as the likely future path of monetary policy. Starting in February 1994, the post FOMC meeting press releases began to signal changes in the Federal funds rate target without explicitly stating the target. When no post meeting statement was released this was taken to signal no change in the Fed funds target. It is natural to ask whether this increased transparency has reduced the uncertainty about future monetary policy. 
We investigate the empirical impact of monetary policy transparency using as a proxy

for the various sources of uncertainty about future monetary policy the forecast dispersions for T-bills from the Survey of Professional Forecasters (SPF).

Data plots and sample statistics suggests that the Fed has been successful at reducing uncertainty about future monetary policy. The broader empirical question is what else might account for the decline in forecast dispersion other than the increase in the transparency of monetary policy. Thus it is necessary to control for that the absolute size of the changes in the Federal funds and the occurrence of financial crises when estimating the impact of transparency on the forecast dispersion of T-bill.

Our findings from the single equation econometric modeling show that the biggest impact of the change in monetary policy transparency occurred in 1994 and 1995: the forecast dispersions decreased by $-20 \%$ to $-30 \%$ of the sample mean for the 1,2 and 3 quarter ahead $\mathrm{T}$ bill forecasts. The range of the decrease in forecast dispersions is similar for the 4 and 5 quarter ahead forecast dispersions, although the estimates are not statistically significant. Thus our estimates suggest that controlling for financial/political crisis and the absolute value of the change in the Federal funds rate, the changes in monetary policy transparency introduced in 1994 and 19995 resulted in a large reduction in uncertainty about future monetary policy 1 to 3 quarters into the future.

We finally perform structural vector autoregressions (SVAR) to characterize the dynamic impact of economic and monetary policy on the T-bill rate forecast dispersion. Overall the empirical results suggest that shocks to inflation, the unemployment rate and the Federal funds rate have a temporary impact on forecast dispersions and hence uncertainty about future monetary policy. This is consistent with the Fed's monetary 
policy transparency being successful in credibly communicating the future stance of monetary policy as well as the ultimate goals of monetary policy. In conclusion, the empirical findings confirm that Federal Reserve transparency has reduced the uncertainty of future monetary policy anticipated by market participants.

\section{References}

Ang, Andrew, Gaert Bekaert and Min Wei (2006), "Do Macro Variables, Asset Markets or Surveys Forecast Inflation Better”, Staff Working Paper \# 2006-15, Federal Reserve Board.

Bernanke, Ben (2007), "Semiannual Monetary Policy Report to the Congress", Testimony Before the Committee on Banking, Housing and Urban Affairs, U.S. Senate, February 14, 2007.

Bernanke, Ben and Ilian Mihov (1998), "Measuring Monetary Policy”, Quarterly Journal of Economics, 113, pp.1025-53.

Carlson, John, BenCraig, Patrick Higgins and William Melick (2006), "FOMC Communications and the Predictability of Near-Term Policy Decisions", Federal Reserve Bank of Cleveland.

Carpenter, Seth (2004), “Transparency and Monetary policy: What Does the Academic Literature Tell Policymakers?” Division of Monetary Affairs, The Board of Governors of the Federal Reserve System, working paper 2004-35.

De Haan, Jakob, Sylvester Eijffinger and Krzysztof Rybinski (2007), “Central Bank Transparency and Central bank Communication: Editorial Introduction”, European Journal of Political Economy, 23, pp. 1-8.

Ehrmann, M. and M. Fratzscher (2007) "Transparency, Disclosure, and the Federal Reserve.” International Journal of Central Banking, 3, pp.179-225.

Ferguson, Roger W. (2001) “Transparency in Central Banking: Rationale and Recent Developments" remarks before the National Economists Club and Society of Government Economists, Washington, D.C. April 19, 2001.

Friedman, Milton (1960), A Program for Monetary Stability, New York: Fordham University Press. 
Geraats, P.M. (2002), “Central Bank Transparency.” The Economic Journal, 112. pp F532-F565.

Greenspan, Alan (1996), “The Challenge of Central Banking in a Democratic Society”, at the Annual Dinner and the Francis Boyer Lecture of the American Enterprise Institute for Public Policy Research, Washington, D.C., December 5, 1996.

Greenspan, Alan, (2001) “The Challenge of Measuring and Modeling a Dynamic Economy”, at the Washington Economic Policy Conference of the National Association for Business Economics, Washington, D.C., March 27, 2001.

Greenspan, Alan (2002), “Economic Volatility”, At the Symposium Sponsored by the Federal Reserve Bank of Kansas City, Jackson Hole, Wyoming, August 30, 2002.

Greenspan, Alan (2004) "Risk and Uncertainty in Monetary Policy", American Economic Review Papers and Proceedings, 94, pp. 33-48.

Issing, O. (2005) “Communication, Transparency, Accountability: Monetary Policy in the Twenty-First Century.” Federal Reserve Bank of St. Louis March/April 2005.

Kohn, Donald (2006) "Monetary Policy and Uncertainty”, At the Fourth Conference of the International Research Forum on Monetary Policy, Washington, D.C., December 1, 2006.

Krane, Spencer (2006), “How Professional Forecasters View Shocks to GDP”, Federal Reserve Bank of Chicago Working Paper \#19.

Meyer, Laurence (2000), "Structural Change and Monetary Policy”, Before the Joint Conference of the Federal Reserve Bank of San Francisco and the Stanford institute for Economic Policy Research, March 3, 2000.

Moskow, M. H. (2006) "Reflection on Monetary Policy: Flexibility, Transparency, and Inflation.” The Federal Reserve Bank of Chicago.

Poole, William (2005a), "FOMC Transparency”, Presentation at the Ozark Chapter of the Society of Financial Services Professionals, October 6, 2004.

Poole, William (2005b), “How Predictable is Fed Policy?” Federal Reserve Bank of St. Louis Review, November/December, pp.659-668.

Saxton, Jim (1997), “Transparency and the Federal Reserve Monetary Policy”, Joint Economic Committee of the United States Congress.

Tetlow, Robert and Brian Ironside (2006), "Real-time Uncertainty in the United States: The Fed From 1996-2003”, European Central Bank Working Paper Series No. 610. 
Walsh, C. E., (2003) “Accountability, Transparency, and Inflation Targeting.” Journal of Money, Credit, and Banking, 35, pp. 829-849.

Williams, John (2004), "Robust Estimation and Monetary Policy with Unobserved Structural Change”. Federal Reserve Bank of San Fransisco, Working Papers Series. 2004-11.

Table 1:

\begin{tabular}{|c|c|c|c|c|c|}
\hline \multicolumn{6}{|c|}{ Mean of Standard deviation of 3 month T-bill survey forecast 1 to 5 quarters ahead } \\
\hline Sample & STF1 & STF2 & STF3 & STF4 & STF5 \\
\hline 81:3 to 93:4 & 0.328 & 0.497 & 0.640 & 0.868 & 1.418 \\
\hline 84:1 to $93: 4$ & 0.233 & 0.357 & 0.502 & 0.732 & 1.269 \\
\hline 94:1 to $06: 3$ & 0.160 & 0.248 & 0.370 & 0.494 & 0.826 \\
\hline 95:4 to $06: 3$ & 0.159 & 0.247 & 0.357 & 0.477 & 0.796 \\
\hline 99:3 to $06: 3$ & 0.157 & 0.275 & 0.384 & 0.499 & 0.765 \\
\hline & & & & & \\
\hline
\end{tabular}

\begin{tabular}{|c|c|c|c|c|c|}
\hline \multicolumn{6}{|c|}{ Percent change in mean dispersion from 1981:3 to 1993:4 sample: } \\
\hline Sample & STF1 & STF2 & STF3 & STF4 & STF5 \\
\hline 94:1 to 06:3 & $-51.2 \%$ & $-50.1 \%$ & $-42.2 \%$ & $-43.1 \%$ & $-41.7 \%$ \\
\hline 95:4 to 06:3 & $-51.5 \%$ & $-50.3 \%$ & $-44.2 \%$ & $-45.0 \%$ & $-43.9 \%$ \\
\hline 99:3 to 06:3 & $-52.1 \%$ & $-44.7 \%$ & $-40.0 \%$ & $-42.5 \%$ & $-46.1 \%$ \\
\hline \multicolumn{6}{|c|}{ Percent change in mean dispersion from 1984:1 to 1993:4 sample } \\
\hline Sample & STF1 & STF2 & STF3 & STF4 & STF5 \\
\hline 94:1 to 06:3 & $-31.3 \%$ & $-30.5 \%$ & $-26.3 \%$ & $-32.5 \%$ & $-34.9 \%$ \\
\hline 95:4 to 06:3 & $-31.8 \%$ & $-30.8 \%$ & $-28.9 \%$ & $-34.8 \%$ & $-37.3 \%$ \\
\hline 99:3 to 06:3 & $-32.6 \%$ & $-23.0 \%$ & $-23.5 \%$ & $-31.8 \%$ & $-39.7 \%$ \\
\hline
\end{tabular}


Table 2: Sample: 1984:1 2006:3, observations $=91$

\begin{tabular}{|c|c|c|c|c|c|}
\hline & STF1 & STF2 & STF3 & STF4 & STF5 \\
\hline Mean & 0.19 & 0.30 & 0.43 & 0.60 & 1.02 \\
\hline Median & 0.16 & 0.27 & 0.39 & 0.51 & 0.87 \\
\hline Maximum & 0.85 & 0.72 & 0.88 & 2.59 & 3.39 \\
\hline Minimum & 0.06 & 0.12 & 0.18 & 0.24 & 0.31 \\
\hline Std. Dev. & 0.12 & 0.12 & 0.16 & 0.34 & 0.60 \\
\hline & \multicolumn{5}{|c|}{ Sample autocorrelations (standard error $=0.21$ ) } \\
\hline Lag 1 & 0.11 & 0.54 & 0.40 & 0.24 & 0.13 \\
\hline 2 & 0.09 & 0.45 & 0.48 & 0.14 & 0.12 \\
\hline 3 & 0.10 & 0.36 & 0.35 & 0.16 & 0.12 \\
\hline \multirow[t]{2}{*}{4} & -0.07 & 0.27 & 0.27 & 0.39 & 0.31 \\
\hline & \multicolumn{5}{|c|}{ Unit root tests ${ }^{*}$} \\
\hline $\begin{array}{l}\text { ADF test statistic } \\
\text { (probability) }\end{array}$ & $\begin{array}{l}-8.45 \\
(0.00)\end{array}$ & $\begin{array}{c}-3.84 \\
(0.00)\end{array}$ & $\begin{array}{l}-3.52 \\
(0.01)\end{array}$ & $\begin{array}{c}-2.52 \\
(0.11)\end{array}$ & $\begin{array}{l}-1.90 \\
(0.33)\end{array}$ \\
\hline
\end{tabular}

*Augmented Dickey Fuller test with lag length chosen using the Schwartz information criterion.

Comments on Table 2: 
1) The mean, median, minimum and standard deviation of the forecast dispersion (standard deviation of forecasts) increases with the forecast horizon. The maximum also increases going from the 2 to 5 quarters ahead forecast dispersion.

2) Unit root tests indicate that the 1 to 3 quarters ahead forecast dispersions are stationary. The 4 and 5 quarters ahead forecast dispersions appear to be nonstationary. 3) The sample autocorrelations indicate that the 1 quarter ahead forecast dispersions are serially uncorrelated. Lags 1 to 3 of the 4 and 5 quarters ahead forecast dispersions are not serially correlated, while the fourth lag is. However this series is nonstationary. Does this make sense? The 2 and 3 quarters ahead forecast dispersions are serially correlated.

Table:3 Sample 1984:1 to 2006:3

\begin{tabular}{|c|c|c|c|c|c|c|}
\hline Date & STF1 & STF2 & STF3 & STF4 & STF5 & Event \\
\hline $84: 1$ & & 0.43 & 0.57 & & 1.92 & Monetary tightening (+26 bps) \\
\hline $84: 2$ & & 0.43 & 0.67 & 2.59 & 2.70 & Monetary tightening (+87 bps) \\
\hline 84:3 & & 0.47 & 0.72 & 0.98 & & Monetary tightening (+87 bps) \\
\hline 84:4 & 0.36 & 0.58 & 0.73 & 0.96 & & Monetary ease (-212 bps) \\
\hline $85: 1$ & 0.48 & 0.72 & 0.88 & 0.99 & 3.39 & Monetary ease (-79 bps) \\
\hline $85: 2$ & 0.32 & 0.59 & 0.79 & 1.80 & 1.89 & Monetary ease (-55 bps) \\
\hline $85: 3$ & & & 0.64 & & 1.75 & No change in monetary policy \\
\hline $85: 4$ & & & 0.59 & & & Monetary tightening (20 bps) \\
\hline 86:1 & & & & & 2.06 & Monetary ease (-28 bps) \\
\hline 86:2 & 0.38 & 0.46 & & & & Monetary ease (-90 bps) \\
\hline $87: 1$ & 0.52 & & & & 1.79 & No change in monetary policy \\
\hline $87: 4$ & 0.34 & 0.52 & 0.61 & & 1.72 & Stock market crash \\
\hline 89:1 & & & 0.59 & & 2.30 & Monetary tightening (+97 bps) \\
\hline 89:2 & & 0.45 & 0.64 & & 2.17 & Monetary tightening (+28 bps) \\
\hline 89:3 & & 0.47 & 0.67 & & & Monetary ease (-64 bps) \\
\hline $90: 1$ & & & 0.69 & & & Monetary ease (-36 bps) \\
\hline $90: 3$ & & & & & 2.03 & No change in monetary policy \\
\hline 91:1 & & & & & 2.20 & Monetary ease (-132 bps) \\
\hline $91: 2$ & & & & 1.61 & 1.66 & Monetary ease (-56 bps) \\
\hline $92: 1$ & 0.32 & & & & & Monetary ease (-80 bps from previous quarter) \\
\hline $92: 3$ & 0.57 & 0.59 & 0.66 & & & Monetary ease (-50 bps from previous quarter) \\
\hline 93:2 & & & & 1.09 & & No change in monetary policy \\
\hline 93:3 & & & 0.63 & & & No change in monetary policy \\
\hline 95:1 & & & & & 2.03 & Monetary tightening (+64 bps) \\
\hline 95:3 & & & 0.87 & 0.94 & & Monetary ease (-22 bps) \\
\hline 96:1 & & & 0.84 & & & Monetary ease (-36 bps) \\
\hline $97: 3$ & 0.85 & & & & & Asian financial crisis \\
\hline 98:2 & & & & 1.05 & & No change in monetary policy \\
\hline $98: 4$ & 0.32 & & & & & Russian LTCM crisis, -67 bps ease \\
\hline $00: 1$ & & & & & 1.68 & Monetary tightening (+37 bps) \\
\hline 01:1 & 0.32 & 0.43 & & & & Monetary ease (-88 bps from previous quarter) \\
\hline 01:2 & 0.33 & 0.48 & & & & Monetary ease (-127 bps from previous quarter) \\
\hline 01:4 & 0.31 & & & & & Post 9/11, Monetary ease (-136 bps) \\
\hline
\end{tabular}




\begin{tabular}{|l|c|c|c|c|c|c|}
\hline $04: 1$ & & 0.41 & & & & No change in monetary policy \\
\hline $\begin{array}{l}\text { \# of } \\
\text { spikes }\end{array}$ & 13 & 14 & 17 & 9 & 15 & \\
\hline
\end{tabular}

Note2:

1. Definition of spikes is the mean plus one standard deviation which for the various measures of forecast dispersion works out as: $S T F_{1 t} \geq 0.31, S T F_{2 t} \geq 0.42, S T F_{3 t} \geq 0.59, S T F_{4 t} \geq 0.94$, and $S T F_{5 t} \geq 1.62$

2. Monetary tightening or ease is measured as the change in the Federal funds rate from the previous quarter.

Table 4a Sample period 1984:1 to 2006:3 (t-statistics in parentheses)

\begin{tabular}{|l|c|c|c|c|c|c|}
\hline & \multicolumn{5}{|c|}{ Dependent variable: $S_{1 t}$ (mean $\left.=0.19\right)$} \\
\hline Constant & 0.19 & 0.19 & 0.18 & 0.17 & 0.17 & 0.14 \\
& $(7.38)$ & $(10.16)$ & $(7.14)$ & $(9.67)$ & $(8.42)$ & $(9.25)$ \\
\hline$\left|\Delta F F R_{t}\right|$ & 0.09 & 0.10 & 0.09 & 0.10 & 0.11 & 0.14 \\
& $(2.09)$ & $(3.30)$ & $(2.23)$ & $(3.46)$ & $(2.87)$ & $(4.99)$ \\
\hline$D_{94}$ & -0.07 & -0.10 & & & & \\
& $(-2.11)$ & $(-3.91)$ & & & & \\
\hline$D_{94} *\left|\Delta F F R_{t}\right|$ & 0.03 & 0.06 & & & & \\
& $(0.52)$ & $(1.34)$ & & & & \\
\hline$D_{95}$ & & & -0.06 & -0.08 & & \\
& & & $(-1.66)$ & $(-3.30)$ & & \\
\hline$D_{95} *\left|\Delta F F R_{t}\right|$ & & & 0.03 & 0.06 & & \\
& & & $(0.40)$ & $(1.08)$ & & \\
\hline$D_{99}$ & & & & & -0.07 & -0.04 \\
& & & & & $(-1.89)$ & $(-1.45)$ \\
\hline$D_{99} *\left|\Delta F F R_{t}\right|$ & & & & & 0.04 & 0.01 \\
& & & & & $(0.62)$ & $(0.15)$ \\
\hline $87 C R A S H$ & & 0.14 & & 0.16 & & 0.19 \\
& & $(1.85)$ & & $(1.95)$ & & $(2.23)$ \\
\hline ASIAN & & 0.76 & & 0.76 & & 0.71 \\
& & $(9.86)$ & & $(9.55)$ & & $(8.53)$ \\
\hline$R U S S I A N$ & & 0.12 & & 0.13 & & 0.09 \\
& & $(1.61)$ & & $(1.56)$ & & $(1.08)$ \\
\hline NINE11 & & -0.00 & & 0.00 & & 0.01 \\
& & $(-0.00)$ & & $(0.03)$ & & $(0.10)$ \\
\hline $\bar{R}^{2}$ & 0.16 & 0.61 & 0.14 & 0.59 & 0.15 & 0.54 \\
\hline S.E. of reg & 0.11 & 0.08 & 0.11 & 0.08 & 0.11 & 0.08 \\
\hline Q statistic & & & & & & \\
\hline
\end{tabular}


Table 4b Sample period 1984:1 to 2006:3 (t-statistics in parentheses)

\begin{tabular}{|l|c|c|c|c|c|c|}
\hline & \multicolumn{5}{|c|}{ Dependent variable: $S_{2 t}$ (mean $\left.=0.30\right)$} \\
\hline Constant & 0.28 & 0.27 & 0.27 & 0.25 & 0.23 & 0.14 \\
& $(13.80)$ & $(13.22)$ & $(13.05)$ & $(12.54)$ & $(13.46)$ & $(9.25)$ \\
\hline$\left|\Delta F F R_{t}\right|$ & 0.16 & 0.17 & 0.16 & 0.18 & 0.21 & 0.14 \\
& $(4.87)$ & $(5.33)$ & $(4.92)$ & $(5.40)$ & $(6.77)$ & $(4.99)$ \\
\hline$D_{94}$ & -0.09 & -0.08 & & & & \\
& $(-3.15)$ & $(-2.81)$ & & & & \\
\hline$D_{94} *\left|\Delta F F R_{t}\right|$ & -0.01 & -0.01 & & & & \\
& $(-0.13)$ & $(-0.15)$ & & & & \\
\hline$D_{95}$ & & & -0.06 & -0.06 & & \\
\hline$D_{95} *\left|\Delta F F R_{t}\right|$ & & & -0.02 & $(-2.01)$ & & \\
\hline$D_{99}$ & & & & & & \\
& & & $(-0.31)$ & $(-0.32)$ & & \\
\hline$D_{99} *\left|\Delta F F R_{t}\right|$ & & & & & -0.11 & 0.01 \\
& & & & & $(-1.90)$ & $(0.15)$ \\
\hline $87 C R A S H$ & & 0.24 & & 0.25 & & 0.19 \\
& & $(2.70)$ & & $(2.78)$ & & $(2.23)$ \\
\hline ASIAN & & 0.02 & & 0.02 & & 0.71 \\
& & $(0.24)$ & & $(0.19)$ & & $(8.53)$ \\
\hline RUSSIAN & & 0.05 & & 0.05 & & 0.09 \\
& & $(0.60)$ & & $(0.57)$ & & $(1.08)$ \\
\hline NINE11 & & -0.07 & & -0.06 & & 0.01 \\
& & $(-0.67)$ & & $(-0.59)$ & & $(0.10)$ \\
\hline $\bar{R}^{2}$ & 0.46 & 0.47 & 0.39 & 0.42 & 0.35 & 0.54 \\
\hline S.E. of reg & 0.09 & 0.09 & 0.09 & 0.09 & 0.09 & 0.08 \\
\hline Q statistic & & & & & & \\
\hline
\end{tabular}


Table 4c Sample period 1984:1 to 2006:3 (t-statistics in parentheses)

\begin{tabular}{|c|c|c|c|c|c|c|}
\hline & \multicolumn{6}{|c|}{ Dependent variable: $S T F_{3 t}($ mean $=0.43)$} \\
\hline Constant & $\begin{array}{c}0.43 \\
(13.35)\end{array}$ & $\begin{array}{c}0.42 \\
(12.63)\end{array}$ & $\begin{array}{c}0.43 \\
(13.97)\end{array}$ & $\begin{array}{c}0.42 \\
(13.27)\end{array}$ & $\begin{array}{c}0.36 \\
(14.56)\end{array}$ & $\begin{array}{c}0.36 \\
(13.94)\end{array}$ \\
\hline$\left|\Delta F F R_{t}\right|$ & $\begin{array}{c}0.16 \\
(3.15) \\
\end{array}$ & $\begin{array}{c}0.17 \\
(3.28) \\
\end{array}$ & $\begin{array}{c}0.15 \\
(2.99) \\
\end{array}$ & $\begin{array}{c}0.16 \\
(3.12) \\
\end{array}$ & $\begin{array}{c}0.22 \\
(4.85) \\
\end{array}$ & $\begin{array}{c}0.23 \\
(4.93) \\
\end{array}$ \\
\hline$D_{94}$ & $\begin{array}{c}-0.09 \\
(-2.24)\end{array}$ & $\begin{array}{c}-0.09 \\
(-2.00)\end{array}$ & & & & \\
\hline$D_{94} *\left|\Delta F F R_{t}\right|$ & $\begin{array}{c}-0.05 \\
(-0.63)\end{array}$ & $\begin{array}{c}-0.04 \\
(-0.46)\end{array}$ & & & & \\
\hline$D_{95}$ & & & $\begin{array}{c}-0.10 \\
(-2.47)\end{array}$ & $\begin{array}{c}-0.10 \\
(-2.23)\end{array}$ & & \\
\hline$D_{95} *\left|\Delta F F R_{t}\right|$ & & & $\begin{array}{c}-0.04 \\
(-0.46)\end{array}$ & $\begin{array}{c}-0.03 \\
(-0.30)\end{array}$ & & \\
\hline$D_{99}$ & & & & & $\begin{array}{c}0.01 \\
(0.22)\end{array}$ & $\begin{array}{c}0.01 \\
(0.27)\end{array}$ \\
\hline$D_{99} *\left|\Delta F F R_{t}\right|$ & & & & & $\begin{array}{c}-0.20 \\
(-2.25)\end{array}$ & $\begin{array}{c}-0.21 \\
(-2.02)\end{array}$ \\
\hline 87CRASH & & $\begin{array}{c}0.18 \\
(1.30)\end{array}$ & & $\begin{array}{c}0.19 \\
(1.32)\end{array}$ & & $\begin{array}{c}0.24 \\
(1.67)\end{array}$ \\
\hline ASIAN & & $\begin{array}{c}-0.04 \\
(-0.32)\end{array}$ & & $\begin{array}{c}-0.03 \\
(-0.25)\end{array}$ & & $\begin{array}{c}-0.08 \\
(-0.53)\end{array}$ \\
\hline RUSSIAN & & $\begin{array}{c}-0.00 \\
(-0.03)\end{array}$ & & $\begin{array}{c}0.01 \\
(0.04)\end{array}$ & & $\begin{array}{c}-0.10 \\
(-0.71)\end{array}$ \\
\hline NINE11 & & $\begin{array}{c}-0.11 \\
(-0.69)\end{array}$ & & $\begin{array}{c}-0.10 \\
(-0.62)\end{array}$ & & $\begin{array}{c}-0.01 \\
(-0.05)\end{array}$ \\
\hline $\bar{R}^{2}$ & 0.26 & 0.25 & 0.26 & 0.25 & 0.22 & 0.21 \\
\hline S.E. of reg & 0.14 & 0.14 & 0.14 & 0.14 & 0.14 & 0.14 \\
\hline Q statistic & & & & & & \\
\hline
\end{tabular}


Table 4d Sample period 1984:1 to 2006:3 (t-statistics in parentheses)

\begin{tabular}{|l|c|c|c|c|c|c|}
\hline & \multicolumn{6}{|c|}{ Dependent variable: $S_{4 t}$ (mean = 0.60) } \\
\hline Constant & 0.61 & 0.60 & 0.59 & 0.58 & 0.52 & 0.52 \\
& $(8.31)$ & $(7.82)$ & $(8.44)$ & $(7.98)$ & $(9.14)$ & $(8.75)$ \\
\hline$\left|\Delta F F R_{t}\right|$ & 0.26 & 0.27 & 0.26 & 0.27 & 0.32 & 0.34 \\
& $(2.20)$ & $(2.23)$ & $(2.25)$ & $(2.28)$ & $(3.06)$ & $(3.09)$ \\
\hline$D_{94}$ & -0.15 & -0.13 & & & & \\
& $(-1.52)$ & $(-1.23)$ & & & & \\
\hline$D_{94} *\left|\Delta F F R_{t}\right|$ & -0.17 & -0.21 & & & & \\
& $(-0.92)$ & $(-1.02)$ & & & & \\
\hline$D_{95}$ & & & -0.13 & -0.11 & & \\
& & & $(-1.40)$ & $(-1.08)$ & & \\
\hline$D_{95} *\left|\Delta F F R_{t}\right|$ & & & -0.20 & -0.27 & & \\
& & & $(-1.09)$ & $(-1.25)$ & & \\
\hline$D_{99}$ & & & & & -0.04 & -0.02 \\
& & & & & $(-0.34)$ & $(-0.15)$ \\
\hline$D_{99} *\left|\Delta F F R_{t}\right|$ & & & & & -0.29 & -0.37 \\
& & & & & $(-1.42)$ & $(-1.56)$ \\
\hline $87 C R A S H$ & & 0.21 & & 0.23 & & 0.28 \\
& & $(0.64)$ & & $(0.69)$ & & $(0.86)$ \\
\hline ASIAN & & -0.11 & & -0.11 & & -0.16 \\
& & $(-0.35)$ & & $(-0.34)$ & & $(-0.49)$ \\
\hline RUSSIAN & & -0.08 & & -0.04 & & -0.30 \\
& & $(-0.23)$ & & $(-0.11)$ & & $(-0.93)$ \\
\hline NINE11 & & 0.13 & & 0.21 & & 0.23 \\
& & $(0.35)$ & & $(0.56)$ & & $(0.59)$ \\
\hline $\bar{R}^{2}$ & 0.14 & 0.11 & 0.14 & 0.11 & 0.10 & 0.09 \\
\hline S.E. of reg & 0.31 & 0.32 & 0.31 & 0.32 & 0.32 & 0.32 \\
\hline Q statistic & & & & & & \\
\hline
\end{tabular}


Table 4e Sample period 1984:1 to 2006:3 (t-statistics in parentheses)

\begin{tabular}{|l|c|c|c|c|c|c|}
\hline & \multicolumn{6}{|c|}{ Dependent variable: $S_{5 t}$ (mean = 1.02) } \\
\hline Constant & 1.12 & 1.09 & 1.08 & 1.05 & 0.98 & 0.96 \\
& $(8.52)$ & $(7.99)$ & $(8.59)$ & $(8.07)$ & $(9.71)$ & $(9.23)$ \\
\hline$\left|\Delta F F R_{t}\right|$ & 0.33 & 0.36 & 0.33 & 0.37 & 0.42 & 0.47 \\
& $(1.55)$ & $(1.67)$ & $(1.63)$ & $(1.75)$ & $(2.26)$ & $(2.48)$ \\
\hline$D_{94}$ & -0.32 & -0.30 & & & & \\
& $(-1.88)$ & $(-1.68)$ & & & & \\
\hline$D_{94} *\left|\Delta F F R_{t}\right|$ & -0.23 & -0.21 & & & & \\
& $(-0.70)$ & $(-0.58)$ & & & & \\
\hline$D_{95}$ & & & -0.29 & -0.26 & & \\
& & & $(-1.68)$ & $(-1.46)$ & & \\
\hline$D_{95} *\left|\Delta F F R_{t}\right|$ & & & -0.31 & -0.33 & & \\
& & & $(-0.94)$ & $(-0.87)$ & & \\
\hline$D_{99}$ & & & & & -0.26 & -0.24 \\
& & & & & $(-1.38)$ & $(-1.20)$ \\
\hline$D_{99} *\left|\Delta F F R_{t}\right|$ & & & & & -0.30 & -0.37 \\
& & & & & $(-0.83)$ & $(-0.90)$ \\
\hline $87 C R A S H$ & & 0.61 & & 0.65 & & 0.73 \\
& & $(1.05)$ & & $(1.12)$ & & $(1.26)$ \\
\hline ASIAN & & 0.20 & & 0.20 & & 0.02 \\
& & $(0.34)$ & & $(0.34)$ & & $(0.03)$ \\
\hline RUSSIAN & & -0.40 & & -0.33 & & -0.80 \\
& & $(-0.69)$ & & $(-0.56)$ & & $(-1.39)$ \\
\hline NINE11 & & -0.06 & & 0.09 & & 0.06 \\
& & $(-0.09)$ & & $(0.13)$ & & $(0.09)$ \\
\hline $\bar{R}^{2}$ & 0.13 & 0.11 & 0.13 & 0.11 & 0.11 & 0.10 \\
\hline S.E. of reg & 0.56 & 0.56 & 0.56 & 0.56 & 0.56 & 0.56 \\
\hline Q statistic & & & & & & \\
\hline
\end{tabular}


Figure 1: Federal funds rate and the 3 month T-bill rate

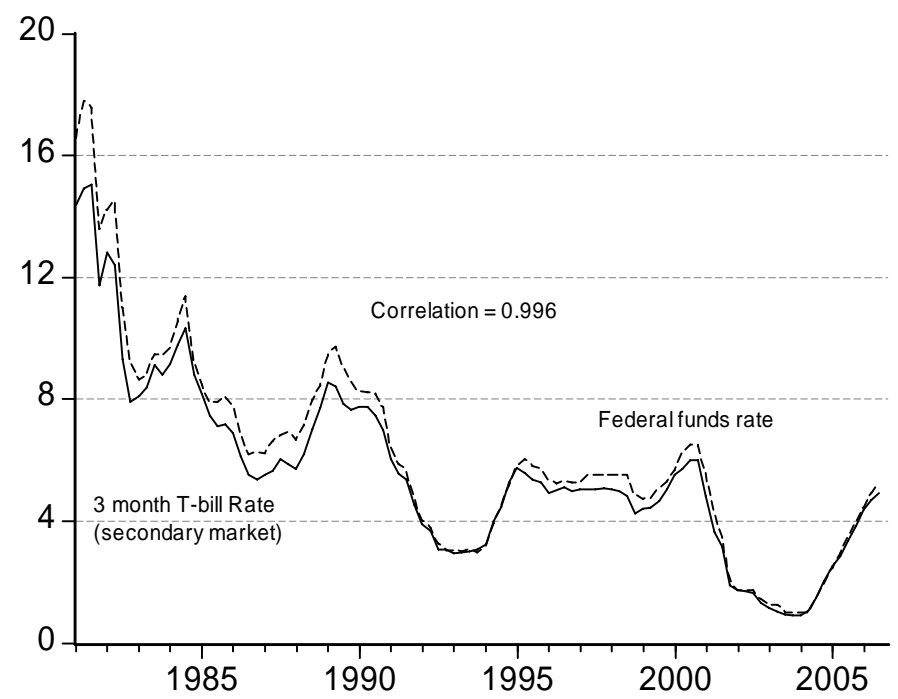


Figure 2: Standard Deviation of the three month T-bill rate (Survey of Professional Forecasters)
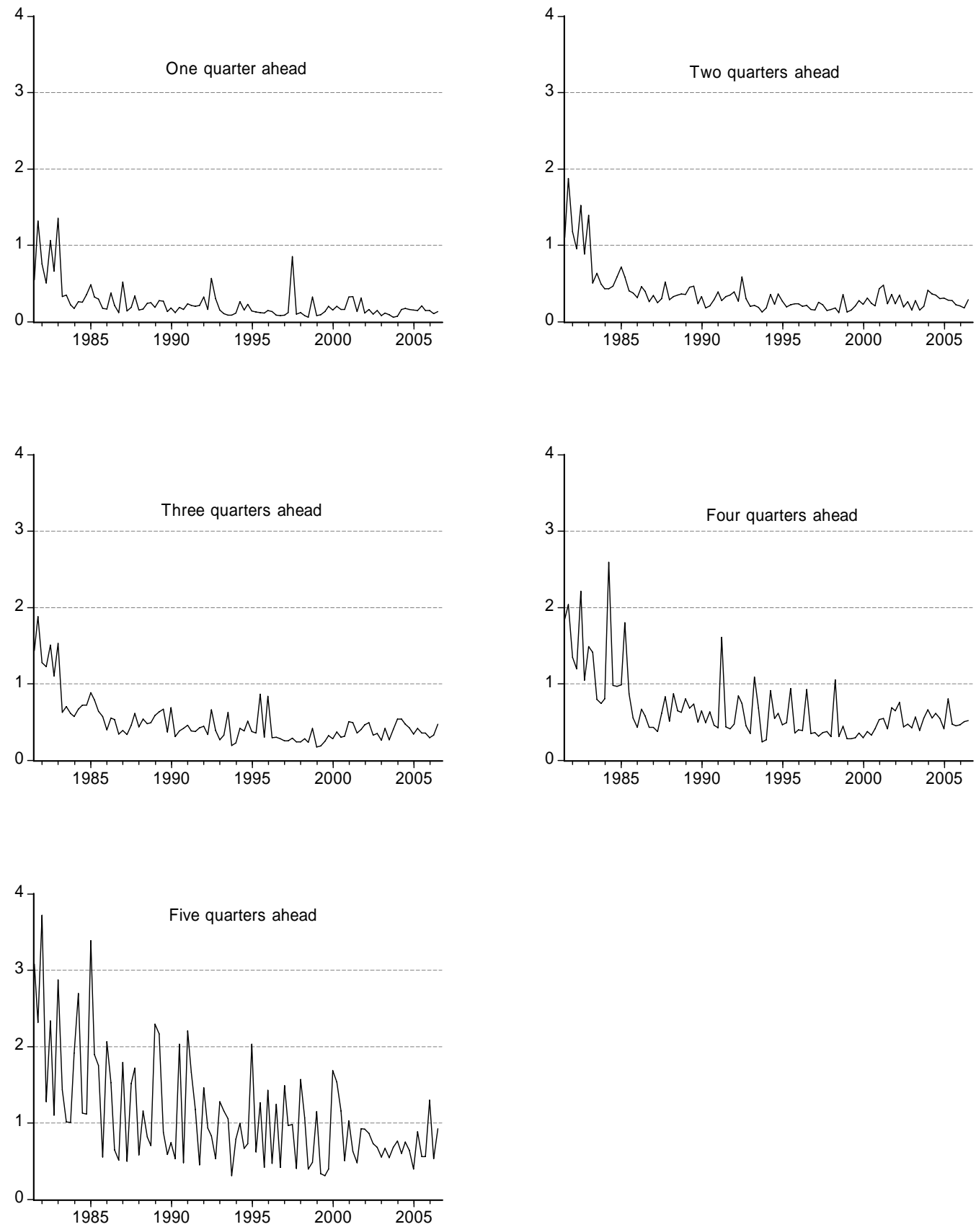


\section{Figure 3a}
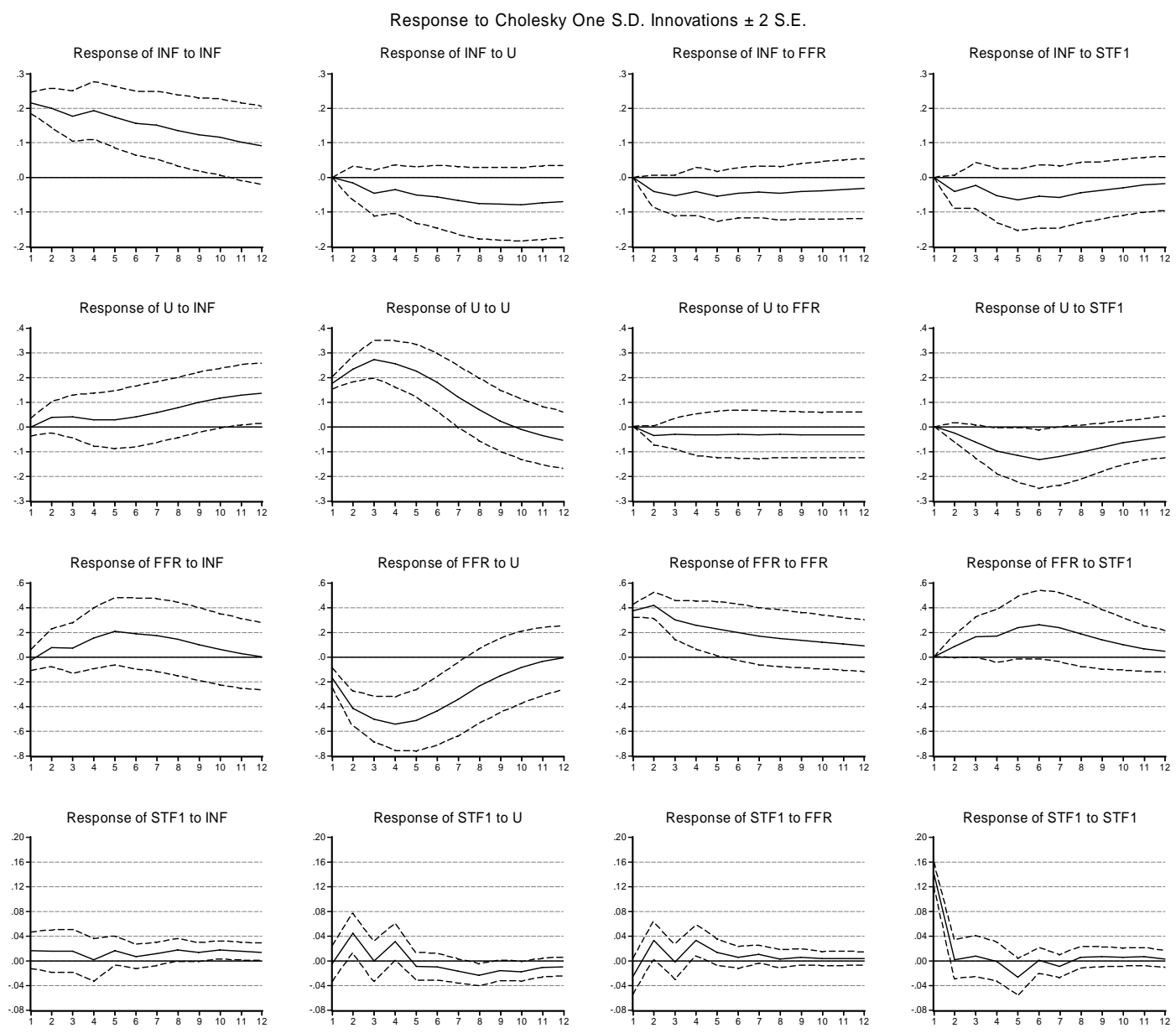


\section{Figure 3b}
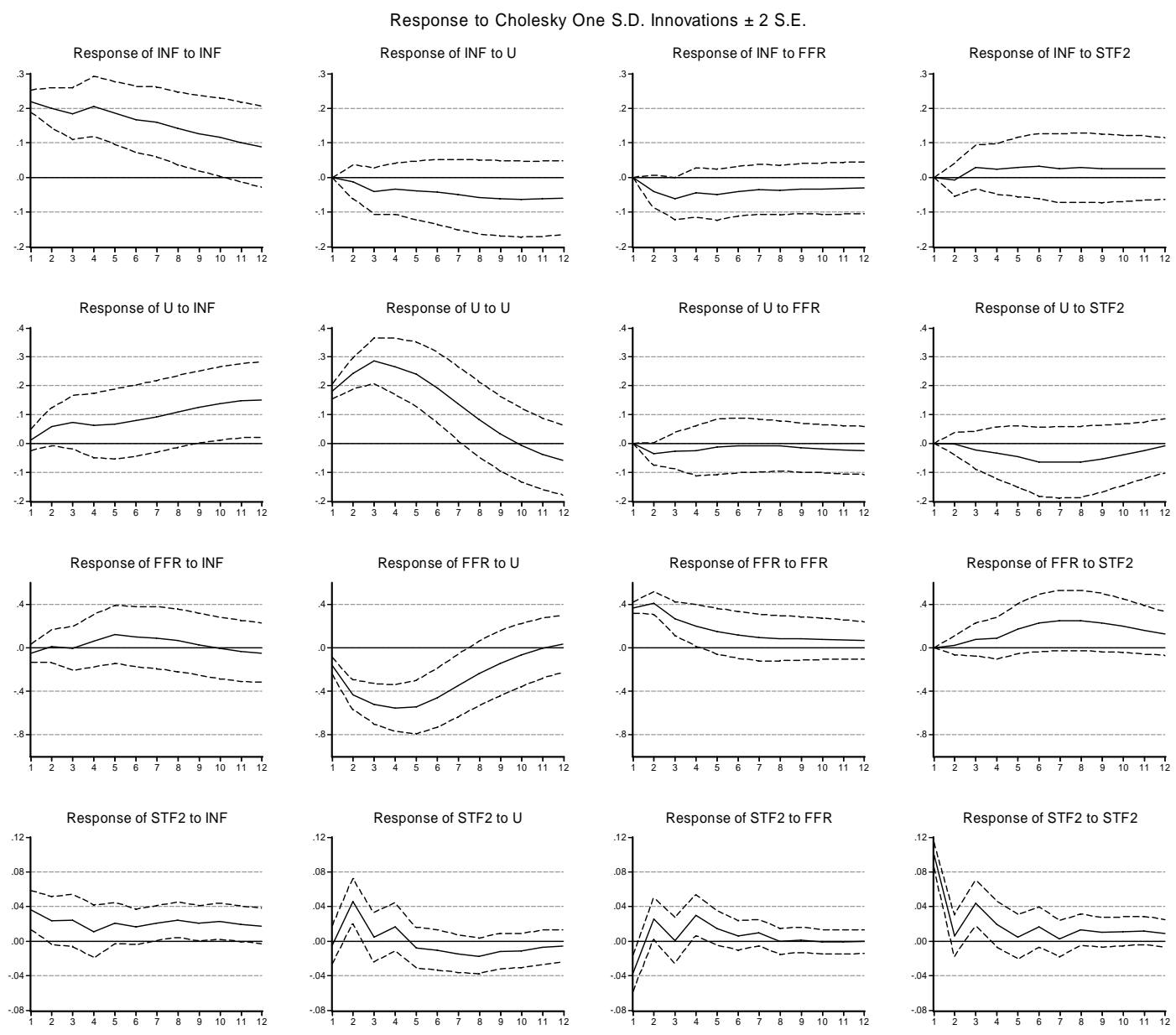


\section{Figure 3c}
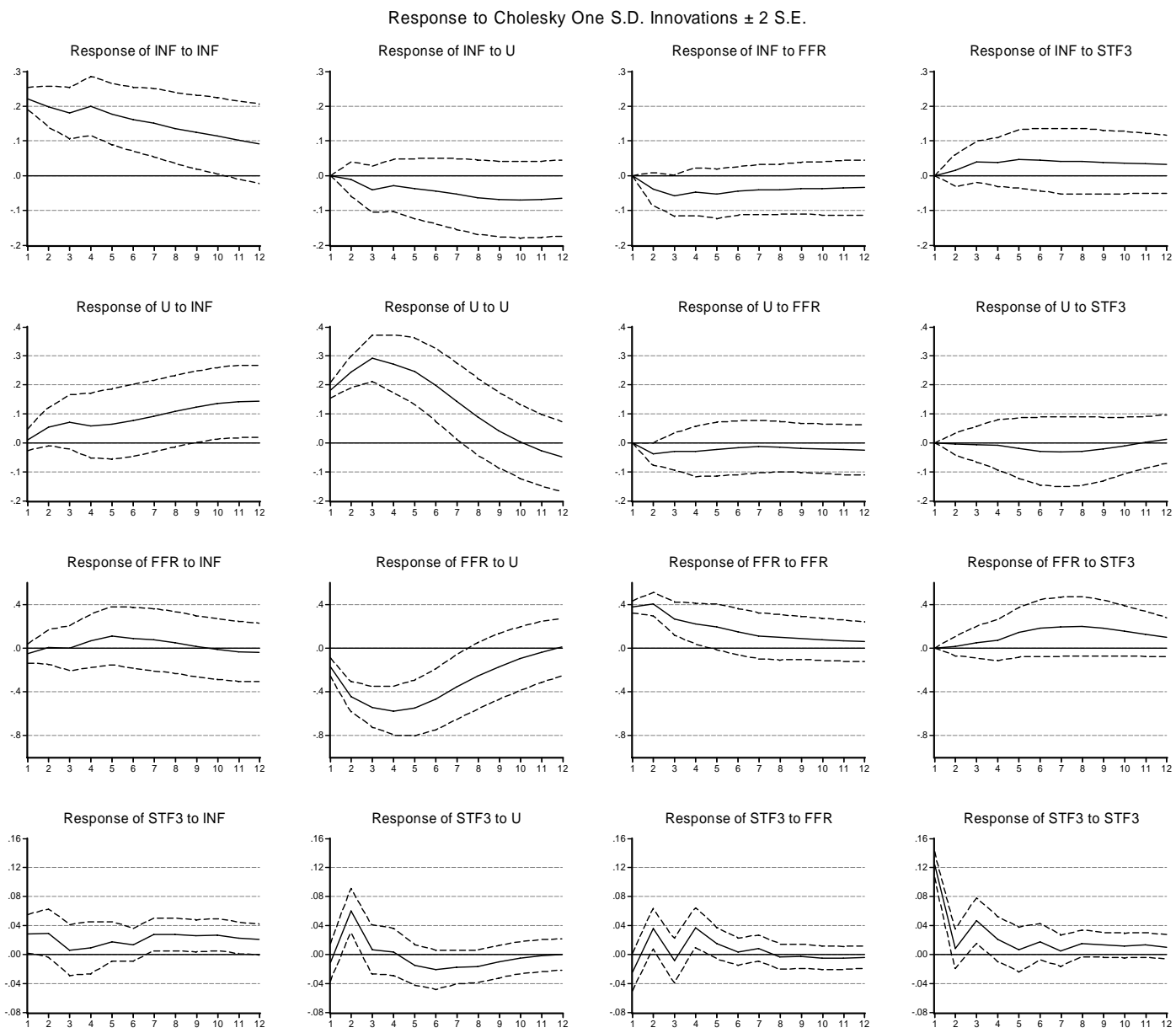


\section{Figure 3d}
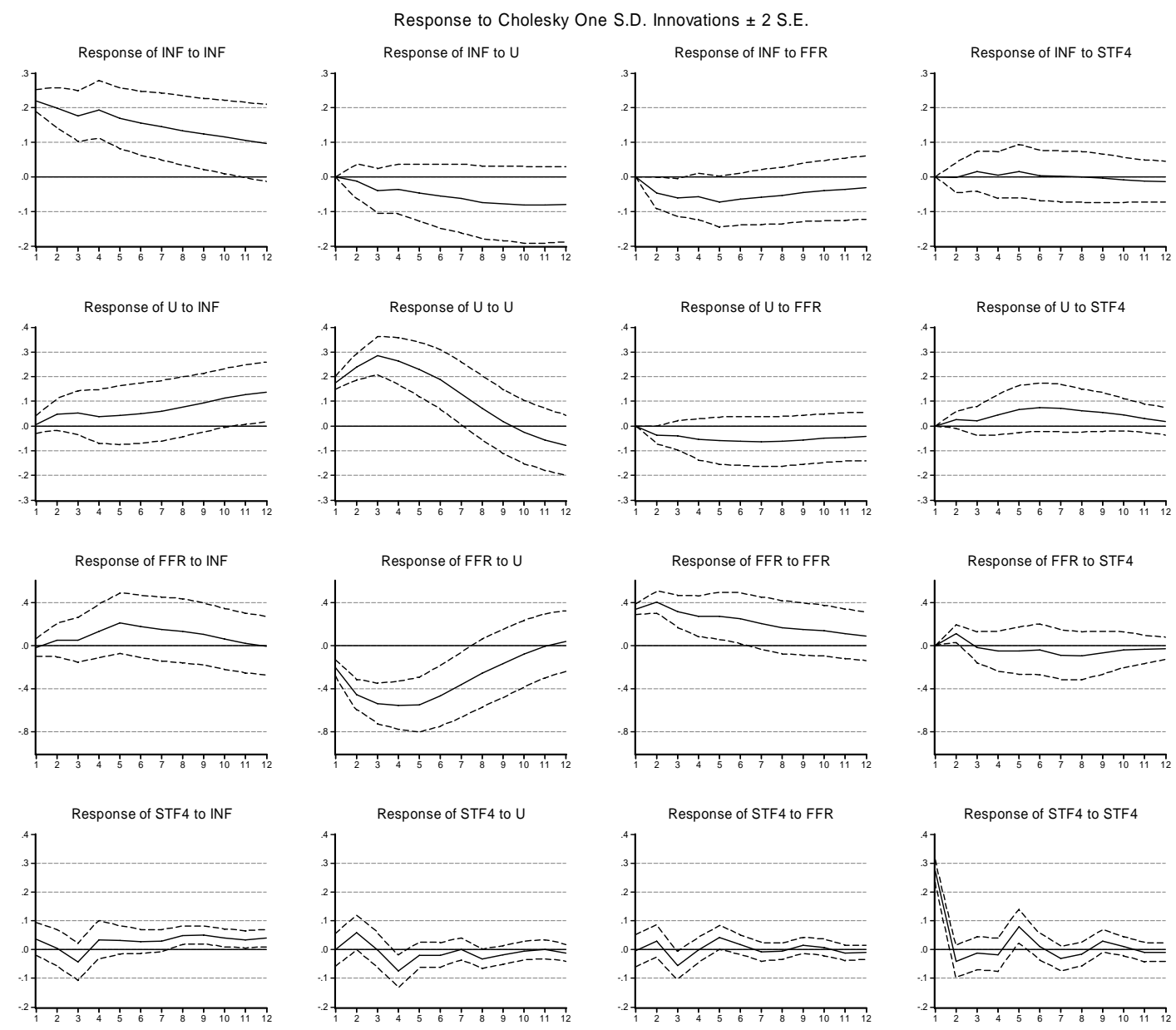


\section{Figure 3e}

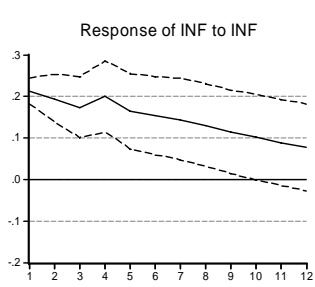

Response of $\mathrm{U}$ to INF

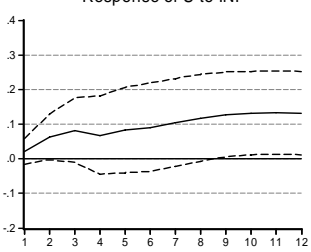

Response of FFR to INF

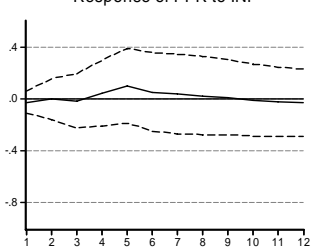

Response of STF5 to INF

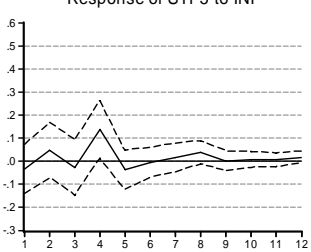

Response to Cholesky One S.D. Innovations \pm 2 S.E.

Response of INF to $U$

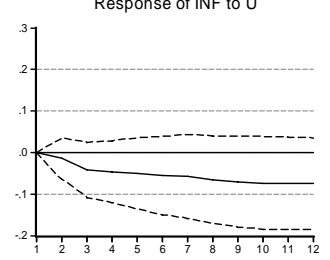

Response of $\mathrm{U}$ to $\mathrm{U}$

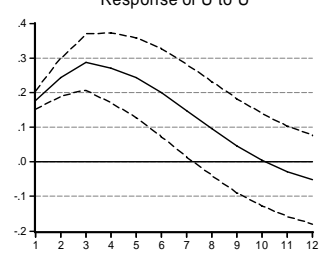

Response of FFR to $U$

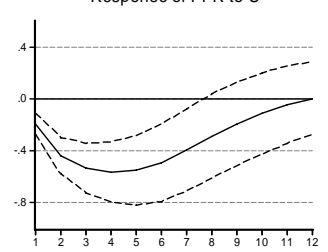

Response of STF5 to U

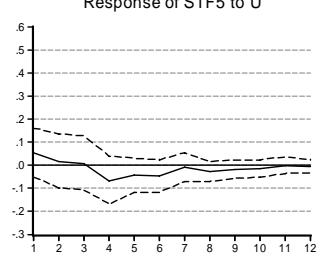

Response of INF to FFR

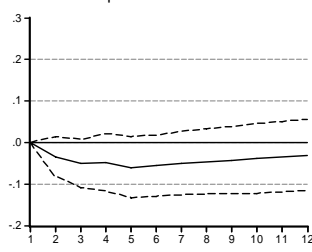

Response of $\mathrm{U}$ to $\mathrm{FFR}$

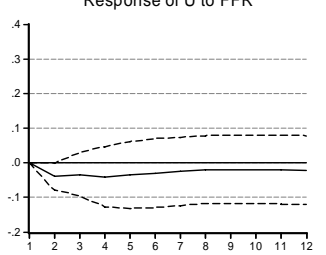

Response of FFR to FFR

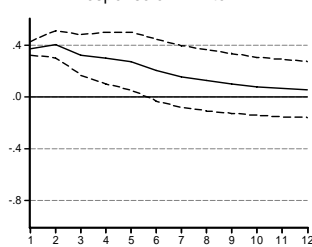

Response of STF5 to FFR

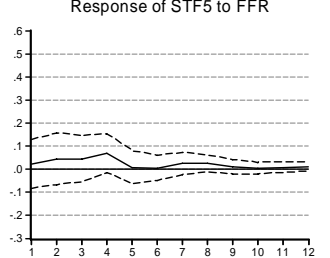

Response of INF to STF5

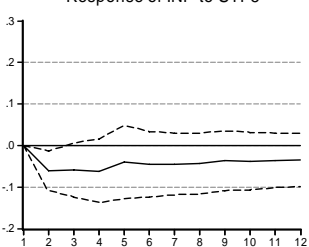

Response of U to STF5

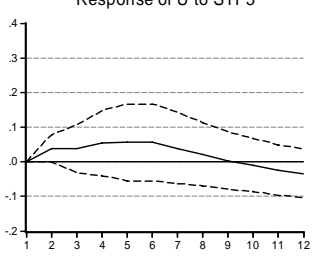

Response of FFR to STF5

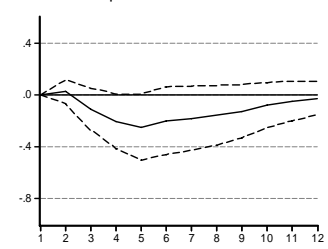

Response of STF5 to STF5

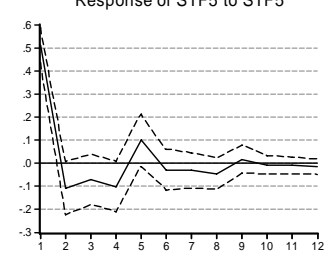

